\title{
METODE PENDIDIKAN KETELADANAN RELEVANSI ANTARA QASIDAH BURDAH DENGAN TEORI BELAJAR SOSIAL ALBERT BANDURA
}

\author{
Intan Budiana Putri \\ Universitas Islam Negeri Sunan Ampel Surabaya, Indonesia \\ Email: intanbudiana99@gmail.com \\ Abdul Muhid \\ Universitas Islam Negeri Sunan Ampel Surabaya, Indonesia \\ Email: abdulmuhid@uinsby.ac.id
}

\begin{abstract}
Abstrak: Dalam pendidikan Islam, keteladanan merupakan metode yang paling banyak terlihat hasilnya dan terbukti bersifat influentif di dalam membentuk moral, spiritual maupun sosial seorang anak. Qashidah Burdah melalui sya'ir-sya'ir nya yang begitu indah, yang menceritakan kisah Rasulullah yang terpilih, ditulis oleh seorang penyair yang alim. Teori belajar sosial menjelaskan bahwa, perilaku dibentuk oleh hubungan yang terjadi antara klien dengan lingkungannya. Modeling adalah salah satu teknik yang disusun oleh Albert Bandura. Tujuan dari riset ini merupakan sebagai sarana untuk menganalisis nilai-nilai pendidikan keteladanan dalam syair-syair qasidah burdah dan relevansinya terhadap teori belajar sosial Albert Bandura. Harapan dari riset ini adalah agar dapat dijadikan sebagai gagasan pendekatan dalam proses pembelajaran untuk mengembangkan kapasitas belajar dengan metode keteladanan. Bentuk riset ini adalah riset kualitatif yang menggunakan metode riset pustaka (library research). Di dalam riset ini ditemukan bahwa di dalam qasidah burdah terdapat kisah-kisah Rasulullah yang dapat kita jadikan sebagai salah satu metode pembelajaran, yaitu metode keteladanan. Hal yang demikian itu sinkron dengan teori belajar sosial Albert Bandura.
\end{abstract}

Kata kunci: Keteladanan, Qasidah Burdah, Albert Bandura.

\section{Pendahuluan}

Menggambarkan keistimewaan Rasullulah yang dilakukan seorang manusia adalah suatu hal yang mustahil dilakukan, hanya Allah yang dapat melukiskannya. Namun para Muta'akhirin berpandangan jika menyanjung dan menghormati Rasulullah Saw. yang agung beserta sifat mahmudah beliau serta kemuliannya merupakan sarana taqorrubilallah, dan termasuk wujud mahabah dan ketaatan kepada Allah, sehingga penyair-penyair saling berlomba menciptakan karya yang berisi syair- 
syair ungkapan keagungan dan penghormatan kepada Rasulullah Saw, termasuk pegarang syair sholawat burdah. ${ }^{1}$

KH. Mustofa Bisri mengungkapkan bahwa "tidak terdapat karya berupa syair yang hingga dikeramatkan melebihi Qasidah Burdah”. Qasidah Burdah mengandung ungkapan mahabbah sebagai wujud kecintaan penyair kepada Nabi ini disusun oleh penyair terkemuka di masanya, beliau adalah Imam Al- Bushiri.

Keteladanan dalam pembelajaran Islam merupakan tata cara yang memberikan impact besar pada tahap persiapan serta pembentukan karakter seorang anak secara moral, spiritual, serta sosial. Pembelajaran merupakan suri tauladan yang baik dalam pemikiran anak, yang berikutnya hendak ditiru (diimitasi) seluruh tingkah lakunya.

Dewasa ini masyarakat Indonesia menggambarkan warga modern yang serba komplek. Keadaan ini disebabkan oleh kemajuan teknologi, mekanisasi, industrialisasi, urbanisasi yang terakhir akibat krisis serta menimbulkan banyak permasalahan sosial. Masalah-masalah sosial yang disangka selaku sosiopatik, secara sosial diketahui dengan patologi sosial semacam penyimpangan tingkah laku, struktur- struktur yang menyimpang, kelompok kelompok deviasi, peranan-peranan sosial, status serta interaksi simbolis yang galat.

Degradasi moral kerap memunculkan kecemasan sosial gap generation, dimana para generasi muda diharapkan bisa menjadi calon-calon pemimpin bangsa. Agar mampu menanggulangi degradasi moral yang berkepanjangan, diperlukannya pembelajaran nilai didalam lembaga sosial, dimulai dari lembaga sosial pertama, yaitu keluarga.

Pembelajaran nilai melalui pembelajaran karakter menjadi salah satu cara yang paling efektif untuk menanggulangi degradasi moral, salah satunya adalah melalui pendidikan keteladanan. Eksperimen yang sudah dilakukan oleh Albert Bandura serta Richard Walters pada kanak-kanak adalah berkenaan dengan peniruan. Dalam eksperimen tersebut menghasilkan gejala, bahwa imitasi bisa berlaku dengan cara

\footnotetext{
${ }^{1}$ Dinul Qoyim, Al-Burdah, T.th, 2. 
pengamatan terhadap sikap model, walaupun pengamatan tersebut tidak dilakukan secara terus menerus.

Artikel ini bertujuan untuk menganalisis nilai-nilai pendidikan keteladanan dalam syair- syair qasidah burdah serta kaitannya terhadap teori belajar sosial Albert Bandura. Riset ini diharapkan bisa dijadikan selaku gagasan pendekatan dalam proses pendidikan buat meningkatkan kapasitas belajar dengan keteladanan, paling utama meneladani Rasulullah SAW. Bersumber pada pembahasan di atas, fokus kajian dalam riset ini merupakan gimana nilai- nilai pembelajaran keteladanan dalam syairsyair qasidah burdah Imam Al-Bushiri serta relevansinya terhadap teori belajar sosial Albert Bandura.

Sofa Muthohar, di dalam penelitiannya yang berjudul Antisipasi Degradasi Moral di Era Global, menemukan bahwa pendidikan Islam melalui strategi yang fungsional, integral dan progresif mampu memberikan solusi degradasi moral pada remaja. Menurut Sofa Muthohar, Strategi ini bisa berupa: pembimbingan problem solving dalam menghadapi persoalan diri dan masyarakatnya serta pembentukan pemahaman secara integral tentang hubungannya dengan Allah. Remaja harus memiliki mental yang dapat merubah dirinya menjadi pribadi yang unggul. ${ }^{2}$

Selain itu, Ali Mustofa dalam penelitiannya yang berjudul Metode Keteladanan Perspektif Pendidikan Islam, mengemukakan bahwa keteladanan dalam pendidikan adalah metode/cara yang efektif dalam mempersiapkan anak dari segi Akhlak, mental dan sosial. Secara psikologi diterapkannya keteladanan sebagai metode pendidikan Islam karena melihat pada dasarnya manusia sejak kecil sudah memiliki rasa ingin meniru pada gerak-gerik atau perilaku orang tua, guru, dan lingkungan. Berkaitan dengan hal tersebut dituntut bagi orang tua, guru memiliki sifat-sifat yang patut diteladani sebagaimana yang dipraktikkan oleh Nabi SAW. ${ }^{3}$

\footnotetext{
2 Sofa Muthohar, "Antisipasi Degradasi Moral di Era Global," Nadwa: Jurnal Pendidikan Islam, vol. 7, no. 2 (2013), 321.

3 Ali Mustofa, "Metode Keteladanan Perspektif Pendidikan Islam," CENDEKIA: Jurnal Studi Keislaman, vol. 5, no. 1 (2019), 23.

166 | Tarbiyatuna: Jurnal Pendidikan Islam; Volume 14, Nomor 2, Agustus 2021 p-ISSN: 2085-6539; e-ISSN: 2242-4579; 164-187
} 
Riset ini merupakan riset kualitatif. Pada riset ini, data ataupun informasi yang dikumpulkan tidak bisa dikuantifikasikan serta lebih bermakna apabila disajikan dalam wujud penjelasan kualitatif. Riset kualitatif memakai prosedur riset pustaka (library research). Riset Pustaka merupakan tata cara riset yang dicoba dengan menekuni referensi serta rujukan tulisan yang relevan dengan kasus yang terjadi dalam riset ini.

Tahapan dalam riset pustaka ini diantaranya, pengumpulan data dan informasi melalui berbagai sumber pustaka. Data pustaka yang didapat digunakan untuk sumber ide dalam rangka menggali pemikiran atau pandangan, selain itu, data pustaka digunakan sebagai referensi dalam rangka mengambil pandangan-pandangan baru sebagai bahan dasar untuk mengembangkan teori baru dari pengetahuan yang telah ada. ${ }^{4}$

Riset ini menggunakan teknik pengumpulan data, yaitu: mengumpulkan referensi-referensi maupun karya tulis yang berhubungan dengan nilai-nilai spiritualitas yang ada pada qasidah burdah. Analisis data yang terdiri dari beberapa tahap kegiatan yaitu pengumpulan data, reduksi data, display data dan penarikan kesimpulan model Miles dan Huberman dipilih dalam riset ini.

Peneliti memilih menggunakan metode ini karena temuan peneliti tersebut bisa dijawab melalui riset pustaka. Studi pendahuluan (preliminary research) yang merupakan salah satu bagian dari studi pustaka diperlukan sebagai salah satu tahap tersendiri, hal ini untuk memahami lebih dalam tentang pendidikan keteladanan yang ada di dalam qasidah burdah, yang kemudian nantinya akan di cari relevansinya dengan teori belajar sosial Albert Bandura. Maka peneliti melakukan riset pustaka untuk mengetahui pendidikan keteladanan dalam qasidah burdah dan relevansinya terhadap teori belajar sosial Albert Bandura.

\section{Metode Pendidikan Keteladanan}

Metodologi pembelajaran ialah sesuatu ilmu pengetahuan tentang tata cara yang dipergunakan dalam pekerjaan mendidik. Metodologi ialah bagian dari disiplin keilmuan yang mempunyai cabang ilmu. Metodologi pembelajaran Islam ialah salah

${ }^{4}$ M. Iqbal Hasan, Pokok-Pokok Materi Metodologi Riset dan Aplikasinya, (Jakarta: Ghalia Indonesia, 2002), 20. 
satu disiplin ilmu didalam ilmu pembelajaran Islam. Dalam pelaksanaannya, banyak menyangkut pengetahuan keilmuan pembelajaran yang bersumber dari Al-Quran dan Hadits. $^{5}$

Metode adalah kumpulan langkah untuk mencapai suatu tujuan. Metode pendidikan keteladanan merupakan cara berupa keteladanan yang dipilih seorang pendidik dalam menyampaikan ilmunya kepada peserta didik.

Menurut istilah, pendidikan adalah suatu langkah yang bersifat memperbaiki, menguatkan, serta menyempurnakan skill serta potensi manusia. Pendidikan diartikan sebagai upaya untuk memupuk moral yang berdasarkan kepada nilai serta kebudayaan yang ada. ${ }^{6}$ Pendidikan juga dipahami sebagai langkah bumanisasi atau sering disebut dengan pembelajaran untuk memanusiakan manusia. ${ }^{7}$ Pendidikan merupakan proses bimbingan dan pendampingan dari guru kepada murid demi terwujudnya insan kamil. ${ }^{8}$

Tidak diragukan bahwa pendidikan yang baik, akan terus melakukan upgrading keilmuan agar menemukan metode yang lebih efektif, yang dapat memberikan pengaruh yang baik kepada anak dalam segala hal. ${ }^{9}$ Hingga akhirnya anak dapat menerima ilmu pengetahuan dengan mudah dan dapat mencapai kematangan yang sempurna. Dalam kitab Tarbiyatul Aulad fil Islam disebutkan bahwa pendidikan keteladanan adalah salah satu metodologi pendidikan Islam. Islam adalah agama yang mengutamakan makna kasih sayang, pemberi rahmat bagi semua insan. Nilai rahmat tersebut dianggungkan dalam keyakinan ajaran Islam, sebagai konsep Rahmatan Lil Alamin. ${ }^{10}$

Salah satu teknik yang memberikan impact untuk bisa ditirukan yang paling tinggi tingkat efektif dan efisiennya dalam mempersiapkan dan mebentuk peserta didik adalah melalui pendidikan keteladanan. Pendidikan sebagai suri tauladan yang

5 Ishom Achmadi, Kaifa Nurobbi Abnaa Ana. Edited by Hubby dan Al-Fatib El-jawy (Yogyakarta: SJ Press, 2014), 8.

${ }^{6}$ Novan Ardy Wiyani dan Barnawi, Ilmu Pendidikan Islam (Yogyakarta: Ar-Ruzz Media, 2016), 16.

${ }^{7}$ Imam Tholkhah \& Ahmad Barizi, Membuka Jendela Pendidikan (Jakarta: Rajawali Pers, 2004), 14.

${ }^{8}$ M. Ladzi Safrony, Al-Ghazali Berbicara Tentang Pendidikan Islam (Yogyakarta: Aditya Media Publishing, 2013), 24.

${ }^{9}$ Ishom Achmadi, Kaifa Nurobbi Abnaa, 16.

${ }^{10}$ Dinil Abrar Sulthani, "Internalisasi Pendidikan Agama dalam Membentuk Masyarakat Madani," Tarbiyatuna: Jurnal Pendidikan Agama Islam, vol. 14, no. 1 (2021), 91.

168 | Tarbiyatuna: Jurnal Pendidikan Islam; Volume 14, Nomor 2, Agustus 2021 p-ISSN: 2085-6539; e-ISSN: 2242-4579; 164-187 
mahmudah dalam pandangan anak, yang selanjutnya diimitasi dalam segala tingkah lakunya. Rasulullah Muhammad Saw. sebagai uswatun hasanah yang diutus Allah SWT. memberikan tauladan pribadi yang kaffah bagi umat islam diseluruh alam. Allah berfirman di dalam Al-Qur'an, Surat Al-Ahzab ayat 45-46:

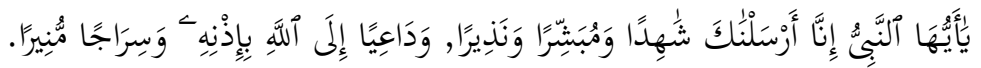

Artinya "Wahai Muhammad, sesunggubnya Kami telah mengutusmu untuk menjadi seorang saksi, dan seseorang yang membawa kabar gemgira dan pemberi peringatan. Dan untuk menjadi penyeru kepada Agama Allah dengan izin Allah dan untuk menjadi cahaya yang menerangi."

Keteladanan Rasulullah dapat dilihat dari berbagai arah, misalnya tentang kejujurannya, dakwahnya, Ibadahnya, qiyamullail-nya, puasanya, istighfar dan tasbihnya, rendah hatinya, lapang dadanya dan lain sebagainya. Rasulullah memberikan uswah kepada manusia untuk menjadi insan kamil yang seimbang antara bablun min Allah dan bablun min al-nas.

Dalam pendidikan Islam, keteladanan memberikan dampak yang besar terhadap proses pembelajaran. Menurut Abdullah Nashih Ulwan, pendidikan dengan memberi teladan secara baik, merupakan faktor yang sangat memberikan impact dalam memperbaiki moral anak, memberi anak arah, dan mempersiapkannya untuk menjadi anggota masyarakat yang secara bersama-sama membangun kehidupan. ${ }^{11}$

Muhammad Jamaluddin al-Qasimy berpendapat, Rasulullah SAW. adalah manusia yang mempunyai uswatun hasanah dan harapan syafaat dari seluruh umat di hari kiamat nanti. ${ }^{12}$ Disaat menghadapi ujian dan cobaan, Rasulullah SAW. mempunyai kekuatan dan kelapangan hati yang luar biasa. Segala ancaman yang datang beliau hadapi dengan tenang, pasrah kepada Allah SWT. dengan segala ketetapan-Nya. Kesulitan yang datang tidak pernah beliau keluhkan. Beliau sangat pandai menghadapi segala situasi. Sabar dan tabah dalam menghadapi segala kesulitan dan cobaan, namun tetap teguh, tegas serta tidak pernah lemah dengan sesuatu yang besar.

${ }^{11}$ Abdullah Nashih Ulwan, Pendidikan Anak dalam Islam, terj. Jamaludin Miri (Jakarta: Pustaka Amani, 2007), 81.

${ }^{12}$ Muhammad Jamaluddin al Qasimy, Tafsir Al Qasimy Al Musamma Mabasinu Al Takwiil (Bairut: Darul Fikr, 1914), 13. 
Dalam proses belajar mengajar, metode contoh (keteladanan) dapat diterapkan dengan dua langkah, yaitu secara langsung (direct) maupun tidak langsung (indirect). Penerapan secara langsung dilakukan dengan cara aktualisasi pendidik secara baik untuk menjadi contoh (uswatun hasanah) bagi anak didiknya. Sedangkan dengan metode tidak langsung (indirect) dengan cara mengisahkan cerita-cerita teladan seperti kisah nabi, cerita tokoh-tokoh besar, pahlawan maupun syuhada'. Hal ini dimaksudkan untuk memberikan suti tauladan yang baik, yang pada akhirnya nanti dapat dipraktikkan di dalam kehidupan peserta didik. ${ }^{13}$

Melalui syair yang indah dan penuh makna, mengisahkan Rasulullah Muhammad SAW. ditulis penyair yang shalih, semoga kita dapat mengikuti keteladanan Rasulullah SAW melalui Qasidah burdah ini.

\section{Qasidah Burdah Syaikh Muhammad Al-Bushiri}

Qasidah burdah merupakan gambaran dari perjalanan religi pengarangnya. Beliau Syaikh Muhammad Al-Bushiri yang mempunyai nama lengkap Abu Abdillah Syaraf Ad-din Muhammad bin Saad bin Hammad bin Muhdin bin Abdillah bin Alshanhaj bin Mallal Al-bushiri. Nama masyhur belia adalah penisbatan dari tempat kelahiran beliau. Oleh As-suyuti, beliau juga dipanggil Al-Dillasi karena ayah beliau yang berasal dari Dallash. Beliau adalah pengikut thoriqoh mu'tabaroh Syadziliyah. Sholawat Burdah merupakan wujud dari besarnya rasa kecintaan beliau kepada Allah dan Rasulullah SAW. ${ }^{14}$

Biografi Rasulullah dan ajaran tasawuf termaktub di dalam qasidah burdah, qasidah burdah merupakan manifestasi dari katya sastra Islam yang mengandung ajaran sufistik. ${ }^{15}$ Spiritualitas Islam tercermin di dalam karya sasrta qasidah burdah. ${ }^{16}$ Burdah merupakan syair al-mada'ih an-Nabawiyyah yang muncul pada awal-awal

${ }^{13}$ Febri Saputra Taklimudin, "Metode Keteladanan Pendidikan Islam dalam Perspektif Quran." BELAJEA: Jurnal Pendidikan Islam, vol. 3, no. 1 (2018), 5.

${ }^{14}$ Ulin Nihayah, "Qasidah Burdah Imam Al-Bushiri; Model Alternatif Dakwah Pesantren." An-Nida: Jurnal Komunikasi Islam, vol. 7, no. 1 (2015), 33.

15 Asep Solikin, "Nilai-Nilai Spiritual Sufistik Qasidah Burdah dalam Meningkatkan Religiusitas." Anterior, Anterior, vol. 15, no. 1 (2015), 21.

${ }^{16}$ Manshur, Kasidah Burdah Al-Busbiry dan Popularitasnya dalam Berbagai Tradisi; Suntingan Teks, Terjemahan dan Telaab Resepsi (Yogyakarta: Universitas Gadjah Mada, 2007), 1.

170 | Tarbiyatuna: Jurnal Pendidikan Islam; Volume 14, Nomor 2, Agustus 2021 p-ISSN: 2085-6539; e-ISSN: 2242-4579; 164-187 
sebelum munculnya karya sastra yang lain. Maka dari itu qasidah burdah dikenal sebagai pelopor syair pujian kepada Rasulullah. ${ }^{17}$

Dalam sejarahnya, pengarang qasidah burdah ini awalnya menderita sakit. Setelah beliau rampung dalam penulisan syairnya, beliau bermimpi bertemu dengan Rasulullah. Beliau mengusapkan tangan dan menyelimutinya. Hingga beliau bangun dan dalam keadaan sembuh dari sakitnya. ${ }^{18}$

Selain itu burdah juga sering digunakan sebagai wasilah syafaat dan rahmat dari Allah dalam mendapatkan kesembuhan dari berbagai macam penyakit dan berbagai macam masalah. As-Shihab Bahaad Ad-Din bin Ali Muhammad, salah satu sahabat dari Al Bushiri pernah meminta salinan burdah untuk pengobatan salah satu pegawai istana kerajaan yang buta. Maka dengan izin Allah SWT. pegawai istana tersebut sembuh dari buta nya. ${ }^{19}$

\section{Teori Belajar Sosial Albert Bandura}

Secara etimologi, psikologi berasal dari kata Psiche yang maksudnya jiwa serta kata logos yang berarti ilmu ataupun pengetahuan, psikologi kerap dimaksud dengan ilmu pengetahuan tentang jiwa, ataupun ilmu jiwa. ${ }^{20}$ Psikologi ataupun ilmu jiwa ialah ilmu yang menekuni tingkah laku serta tanda- tanda kejiwaan pada manusia. ${ }^{21}$

Psikologi pembelajaran ialah riset tentang pendidikan, pengajaran serta orang yang belajar. Psikologi pembelajaran merupakan penggabungan antara pengetahuan, kebijaksanaan, serta teori yang didasarkan pada pengalaman yang dipunyai tiap guru buat membongkar permasalahan pengajaran tiap hari dengan baik. Psikologi pembelajaran tidak bisa menginformasikan kepada guru apa yang wajib dicoba, namun bisa berikan arti prinsip buat digunakan dalam mengambil keputusan yang lebih baik buat mendalami pengalaman serta pemikiran mereka. ${ }^{22}$

${ }^{17}$ Ulin Nihayah, Qasidah Burdah Imam Al-Bushiri, 33.

${ }^{18}$ Dinul Qoyim. Al Burdah, 2.

${ }^{19}$ Ulin Nihayah, Qasidah Burdab Imam Al-Busbiri, 36.

${ }^{20}$ Bimo Walgito, Pengantar Psikologi Umum, (Yogyakarta: Andi Offset, 2004), 1.

${ }^{21}$ Kartini Kartono, Psikologi Sosial Untuk Manajemen Perusabaan dan Industri, Jakarta: PT Raja Grafindo Persada, 2002), 35.

22 Abdul Muhid, Psikologi Pendidikan, (Surabaya: Digilib Uinsa, 2015), 1. 
Manusia cenderung meniru apa yang sudah diperbuat oleh orang lain, perihal ini ialah watak biologis manusia. Tiap orang pula mempunyai kecenderungan serta kemauan yang kokoh buat meyamai apalagi melibihi aksi orang lain disekitarnya. Dalam transmisi kebudayaan serta pengetahuan dari satu generasi ke generasi selanjutnya imitasi memerankan peranan yang sentral. Dalam perkembangannya teori imitasi yang alamiah tersebut secara bertahap, pakar psikologi meninggalkannya, serta menggantikannya dengan beberapa kerangka teoritis yang berkata kalau kecenderungan buat meniru orang lain merupakan suatu yang dipelajari (learned) ataupun didapatkan lewat proses pengondisian supaya seorang cuma melaksanakan peniruan terhadap sikap tertentu.

Albert Bandura serta Richard Walters sudah melaksanakan eksperimen pada kanak- kanak. Hasil eksperimen menampilkan kalau peniruan bisa terjalin cuma lewat pengamatan terhadap sikap model, walaupun pengamatan itu tidak dicoba terus menerus. Teori sosial learning berkata kalau, interaksi antara klien dengan area bisa memodifikasi sesuatu sikap. Metode modeling merupakan salah satu metode konseling yang disusun cocok teori Albert Bandura. Metode modeling ini digunakan apabila tujuan konseling merupakan membentuk sikap baru untuk klien. Prinsip dasar dari metode modeling merupakan klien hendak mendapatkan sikap baru, lewat imitasi ataupun peniruan terhadap seseorang ataupun sebagian orang model. Tetapi bagi Hansen, dengan memakai jenis model tertentu modeling bisa pula buat melenyapkan ataupun kurangi sikap tertentu. ${ }^{23}$

Perspektif agen diadopsi oleh teori kognitif sosial buat pertumbuhan manusia, menyesuaikan diri, serta pergantian. Teori ini membedakan antara 3 fashion agensi: agensi individu dicoba secara individual; agen proxy dicoba buat mengamankan hasil yang diidamkan dengan mempengaruhi orang lain buat berperan atas nama mereka; serta agen kolektif dicoba dengan berperan bersama buat membentuk masa depan. ${ }^{24}$

23 Tarsono, "Implikasi Teori Belajar Sosial (Social Learning Theory) dari Albert Bandura dalam Bimbingan dan Konseling," Psympathic, vol. 3, no. 1 (2010), 32.

${ }^{24}$ Albert Bandura, "Social Cognitive Theory in Cultural Context." Applied Psychology, vol. 51, no. 2 (2002), 280.

172 | Tarbiyatuna: Jurnal Pendidikan Islam; Volume 14, Nomor 2, Agustus 2021 p-ISSN: 2085-6539; e-ISSN: 2242-4579; 164-187 
Kemajuan revolusioner dalam teknologi elektronik sudah mengganti watak, jangkauan, serta lokus pengaruh manusia. Kenyataan sosial baru tersebut sediakan peluang luas untuk orang- orang buat bawa pengaruh mereka pada pertumbuhan individu mereka dan buat membentuk masa depan sosial.

Dalam berhubungan, orang melaksanakan pengamatan terhadap orang lain. Pada tehnik peniruan (modeling) terjalin imitasi peniru kepada orang lain yang dianggap sebagai model. ${ }^{25}$ Pembelajaran melalui pengamatan (observasional learning) terbagi menjadi 4 macam, yaitu attentional proces (orang muncul, serta secara akurat menguasai sikap model), retentional proces (orang mengingat, retensi jangka panjang, sikap model yang tadinya diamati), motor reproduction on proces (seorang menerjemahkan memori yang dikodekan secara simbolis dari sikap model ke dalam pola respons baru), serta motivasional process bila penguatan positif (eksternal, perwakilan, ataupun penguatan diri) muncul secara potensial, orang melaksanakan sikap yang dimodelkan.

Menurut Nelson-Jones, tidak hanya observational learning, kegiatan belajar mengajar dapat berlangsung dengan metode enactive learning (belajar melalui kedudukan) ataupun belajar dari pengalaman. Dalam enactive learning, orang menekuni akibat yang menyertai sesuatu sikap. Berdasarkan pengalamannya terhadap akibat tersebut, orang hendak lebih meningkatkan keterampilannya sampai dia menciptakan sesuatu wujud sikap yang lebih baik. ${ }^{26}$

\section{Kandungan Keteladanan dalam Qasidah Burdah}

Berdasarkan pemaparan di atas, dapat diketahui bahwa di dalam qasidah burdah terdapat pendidikan keteladanan. Kita seharusnya meneladani Rasulullah baik dalam perkataan, perbuatan ataupun dalam segala hal untuk berusaha menjadi insan kamil. Metode yang sangat penting dalam pembelajaran, salah satunya adalah pemberian teladan yang baik. ${ }^{27}$

Naluri untuk meniru orang lain melekat pada jiwa setiap orang. Terutama jika ada hubungan yang menyebabkan mereka lebih dekat. Baik dekat secara langsung fisiknya atau bahkan dekat karena memiliki ideologi yang sama. Kedekatan

${ }^{25}$ Tarsono, Implikasi Teori Belajar Sosial, 31.

${ }^{26}$ Tarsono, Implikasi Teori Belajar Sosial, 31.

27 Abudin Nata, Akblak Tasawnf (Jakarta: Raja Grafindo Persada, 1996), 45. 
memberikan pengaruh yang signifikan pada setiap orang. Bahkan ada sebuah ungkapan, jika kita ingin mengetahui watak seseorang, maka kita perlu melihat dengan siapa dia bergaul. Karena dari komunitas pergaulannya sedikit banyak juga mempengaruhi dalam pembentukan karakternya. ${ }^{28}$

Islam mengarahkan kepada kita agar dapat meneladani akhlak serta sikap Rasulullah SAW, sebab di dalam diri Rasulullah ada suri tauladan yang baik. ${ }^{29}$ Tata cara tajrid adalah satu diantara banyak cara yang diterapkan oleh penyair terdahulu ketika menjalankan proses membuat syair. Penyair berperan menjadi 2 subjek, walaupun pada sebenarnya satu orang, diri penyair sendiri.

Disatu sisi bertanya, serta disisi lain menanggapi. Disatu sisi menyanjung serta disisi yang lain mencela. Perihal ini menggambarkan tanda-tanda cinta, suatu bayangan yang seolah-olah dia tidak memiliki banyak teman. ${ }^{30}$

Secara global, kami jelaskan di dalam syair berikut:

\begin{tabular}{|c|c|}
\hline شرح & نظم \\
\hline 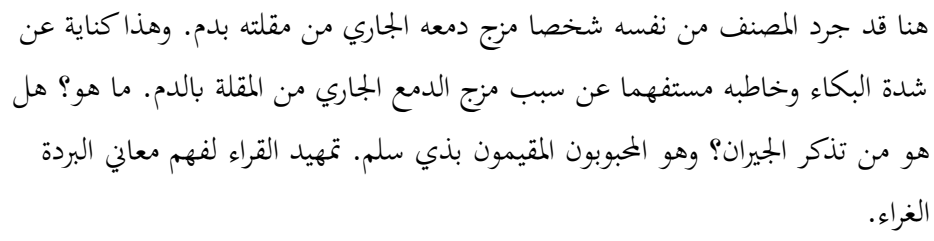 & 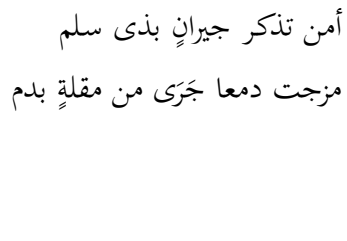 \\
\hline
\end{tabular}

\section{Sumber Syarah ${ }^{31}$}

Seolah-olah penyair menjadi dua peran. Salah satu berperan sebagai seorang objek (atau disebut dengan penjawab). Kalimat bercampur darah pada air mata adalah gambaran hebatnya tangisan orang yang bersyair (penjawab).

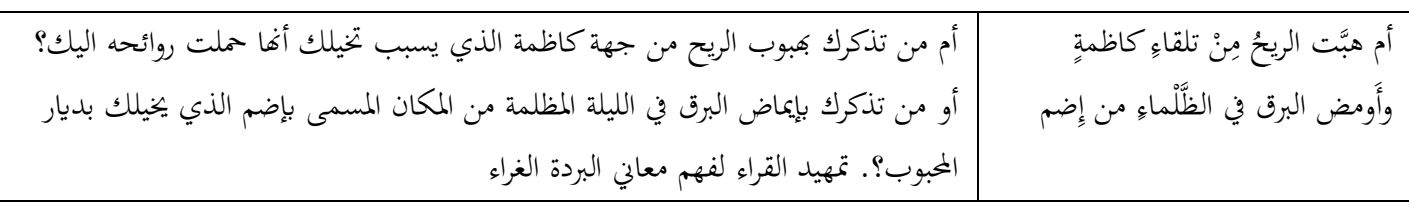

${ }^{28}$ Zarnuji (al), Shaikh. n.d. Ta’lim Al-Muta'allim. Tt. (Surabaya: Al Hidayah, 2010), 34.

${ }^{29}$ Abdul, Asnawi, Muhid, Rangga Sa'adillah. "Pendidikan Moral Melalui Pembelajaran Kitab Alfiyah Ibn Malik di Pondok Pesantren Langitan Tuban." Jurnal Pendidikan Agama Islam Journal of Islamic Education Studies), vol. 6, no. 1 (2018), 106.

${ }^{30}$ Dinul Qoyim, Al Burdah, 7.

${ }^{31}$ Al-Bajuri, Ibrahim, Kitab Syarah Al-Bajuri 'ala Al-Burdah Al-Bushiri, 2. 
Syaikh Muhammad Al Bushiri menggambarkan betapa agung mahabbah Imam Al-Bushiri kepada Rasulullah Muhammad Saw. Beliau menggambarkan bahwa beliau begitu jatuh cinta kepada seorang gadis, yang jika nanti berpisah, pasti akan datang kesusahan dan kepedihan, Mencucurkan air mata yang tiada henti, sampai keluar darah sepanjang waktu siang hingga malam. Akibatnya kurus, pucat hingga beliau sakit.

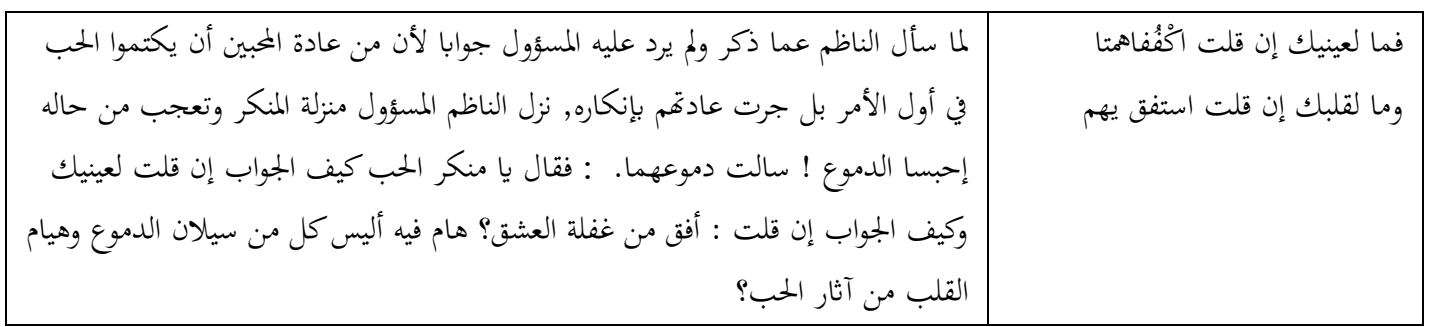

Umunya, pada masa awal percintaan, para pecinta menyembunyikan perasaan cintanya, bahkan terkadang mereka mengingkarinya. Padahal yang demikian itu jelaslah berat dilakukan untuk para pecinta. Mereka tidak akan mampu menahan air mata hingga mereka seperti orang yang kehilanggan kebahagiaan, merana hingga menderita. Semua itu adalah dampak dari perasaan cinta yang amat besar.

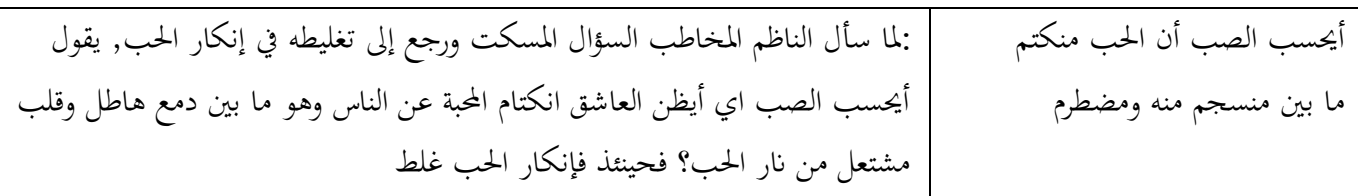

Sebuah kesalahan nyata adalah ketika seseorang yang dimabuk cinta, lalu dia mengingkari cintanya dengan menyembunyikan cintanya diantara tangis dan hati hati yang membara karena besarnya cinta.

\begin{tabular}{|c|c|}
\hline لولا محبتك وهواك لما بكيت على آثار ديار الأحباب ولما ذهب نومك لذكر البان والجبل & 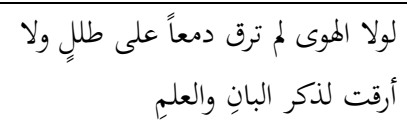 \\
\hline
\end{tabular}

Apa yang telah kamu lakukan sepanjang siang dan malam, tangisanmu atas reruntuhan rumah kekasihmu, atau perasaanmu yang selalu memikirkan cinta hingga engkau susah tidur pada setiap malam adalah bukti besarnya cintamu. Tidak mungkin engkau melakukan semua ini jika bukan karena cinta.

فكيف تنكر حباً بعد ما شهدت به ل وكيف تنكر الحب والعشق وقد قامت عليك الأدلة وعدول الدموع والأسقام شاهدة 
بالحب عليك؟ ولهذا فلا حاجة إلى إنكار

عليك عدول الدمع والسقم

Jika cinta sudah dibuktikan secara nyata oleh seorang saksi yang adil dan dan selalu berkata dan bertindak sesuai dengan kenyataan yang ada, berupa air mata dan derita. Bagaimana mungkin engkau bisa mengingkari cinta tersebut? Tidaklah perlu engkau mengingkari cintamu dihadapanku.

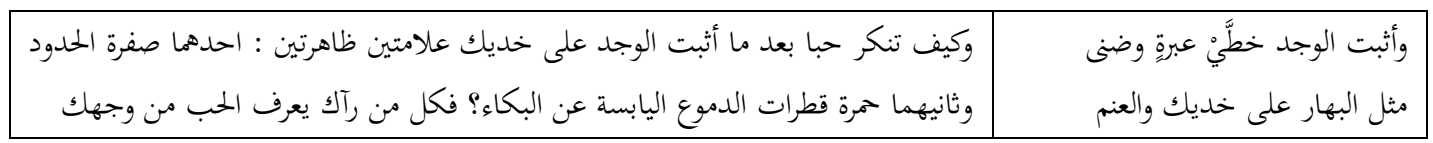

Gimana engkau bisa mengkhianati cintamu, sudah sangat jelas bukti yang nampak di di pipimu? wajahmu yang pucat seperti kuningnya bunga mawar serta air matamu yang berwarna merah semerah bunga mawar merah. Hingga orang-orang yang menjumpaimu hendak paham besarnya cintamu.

Syair tersebut ialah syair penutup dari Syaikh Muhammad Al-Bushiri sebagai orang yang bertanya. Selanjutnya merupakan sya'ir reaksi dari petanyaan yang ditanyakan yang mengandung kata bijak dan penuh nasihat dari orang yang bersyair.

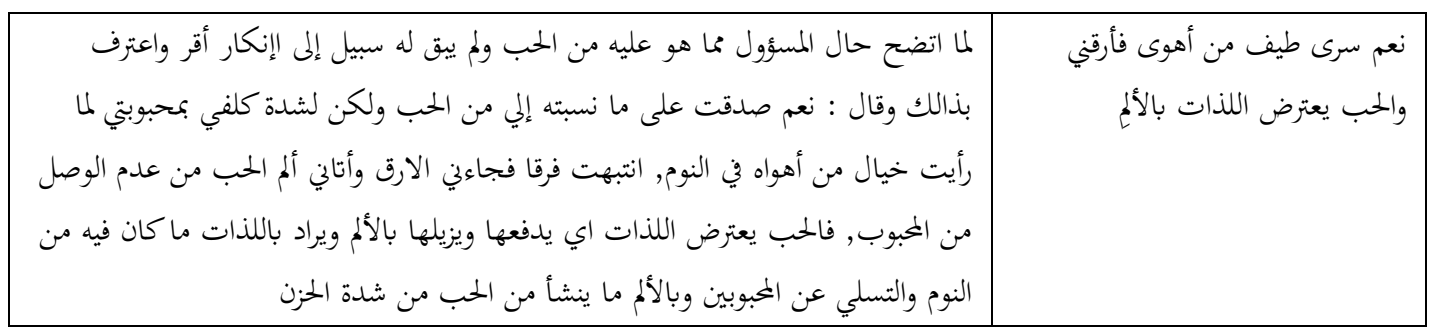

Cinta menghalangiku dari kenikmatan, setelah masalah hilang aku akan jujur dan berkata, Aku merasa sedih karena cinta, mata dan hatiku begitu susah untuk ku pejamkan. Ketenangan dalam tidur yang nyenak, serta harapan untuk bisa bersua adalah suatu kenikmatan, sedangkan pedih ialah besarnya kesedihan akibat cinta.

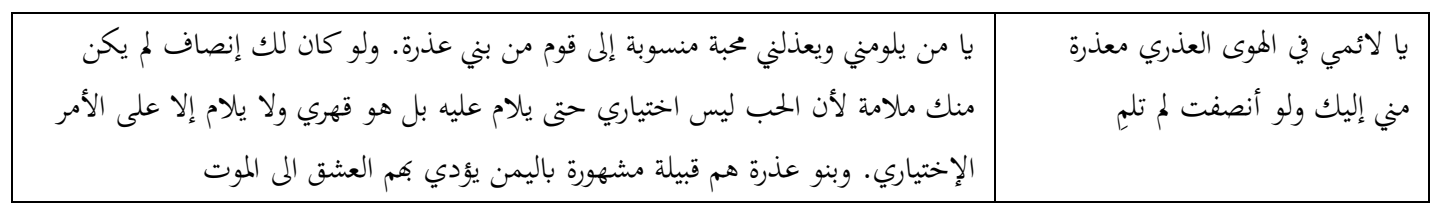


Cinta merupakan suatu yang tiba dengan paksaan. Cinta bukan ikhtiar yang disengaja serta pantas dicerca. Wahai engkau yang menghina kasihku, sebagaimana kasih dari suku Udzroh! Berlagak adillah.

Adapun Suku Udzroh, mereka merupakan sekelompok orang yang terletak di Yaman serta populer dengan sebutan kelompok orang yang suka bercinta serta sering cintanya berakhir pada kematian.

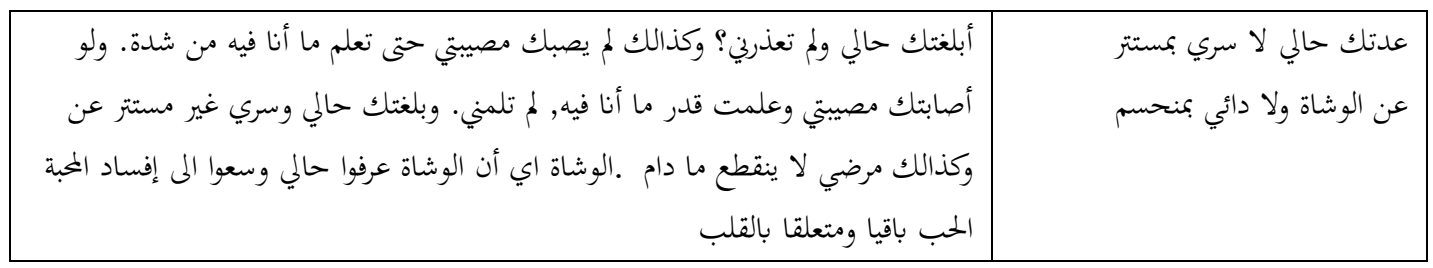

Apakah tidak hingga keadaanku kepadamu? kamu tidak menguasai apa yang saya rasakan, kecuali engkau mengenali dahsyatnya cintaku, baru engkau bisa menguasai dengan baik. Bila engkau memahami cintaku, pasti engkau tidak berkenan mencercaku. Saat ini seluruhnya telah datang kepadamu. Seluruhnya telah terbuka. Begitu pula deritaku, tidak sempat sembuh selagi cinta itu terdapat di dalam hatiku.

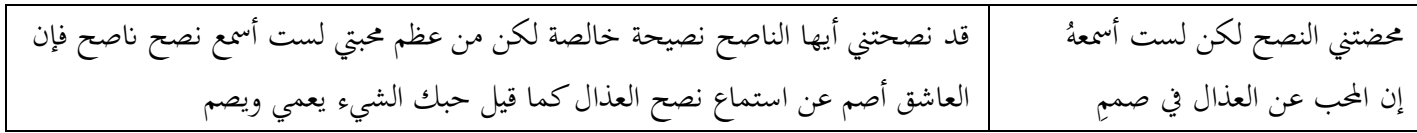

Telinga orang yang jatuh cinta adalah telinga tuli. Sebagaimana kata pepatah: Cintamu pada sesuatu telah membuat dirimu buta serta tuli. Banyak nasehat yang dengan ikhlas datang. Tapi semua tertutup oleh besarnya cinta seseorang.

\begin{tabular}{|c|c|}
\hline 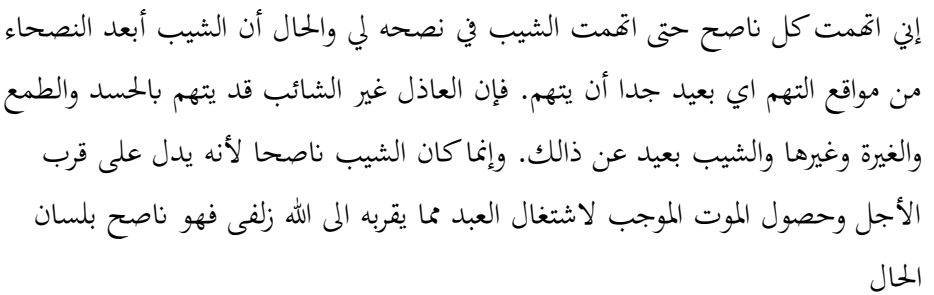 & والشيب أتمت نصيح الشيب في عذلي \\
\hline
\end{tabular}

Saya sudah menuduh seluruh nasihat yang datang, hingga pada ubanku sendiri. Sementara itu sebetulnya ubanku merupakan suatu yang sangat jauh dari kedengkian, tidak sebagaimana pencerca yang lain. Uban sebagai penasihat yang menunjukkan dekatnya kematian. Dengan tumbuhnya uban, manusia sedikit tersadar 
dengan nasehat-nasehat yang selama ini mereka lalaikan. Manusia akan berusaha berbuat baik karena uban sebagai tanda dekatnya dengan kematian.

$$
\text { في من جإن أمارتي بالسوء ما اتعظت }
$$

Aku mempunyai hawa nafsu telah mengarahkanku untuk berperilaku jelek dan lalai dengan kata bijak penasehat. Sampai tumbuhnya uban sebagai tanda dekatnya kematian. Dan kerentaan sebagai tanda kematian.

$$
\text { ضيف ألم بأست من الفعل الجميل قرى }
$$

Jiwa ini belum sampai melakukan persiapan diri dengan bermacam amal kebaikan guna menjamu tamu- tamu yang tiba di kepalaku sendiri, ialah ubanku. Tidak sempat lagi saya menyimpan hormat terhadap tamuku, serta tidak pula saya memiliki rasa malu terhadapnya. Yang diartikan dengan kata "tamu" yakni uban yang mulai berkembang di kepala si penyair.

\begin{tabular}{|c|c|}
\hline من يرد نفسي الأمارة بالسوء عما هو عليه من الضلالة والغواية بالمواعظ السنية كما يرد & 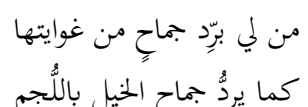 \\
\hline
\end{tabular}

\begin{tabular}{r|r|r|}
\hline كتمت كنت أعلم أني ما أوقره & كعنه \\
\hline
\end{tabular}

Andai saja saya ketahui saat sebelum uban ini berkembang serta saya tidak menghormatinya, hingga hendak kusemir dengan semir gelap buat menyembunyikan rahasiaku.

Kira-kira akankah nafsuku yang tinggi dapat di kekang? Sebagaimana orang mengekang kuda dengan kendali.

فلا ترم بالمعاصي كسر شهوتها


Segala kenikmatan akan membangkitkan keserakahan. Maka dari itu, jangan harap bisa mematahkan hawa nafsumu dengan jalur maksiat.

\begin{tabular}{|c|c|}
\hline 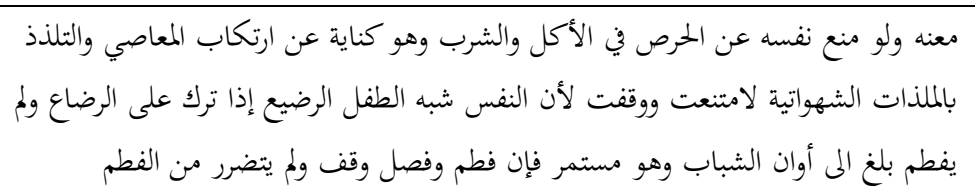 & حب والنفس كالطفل إن تملهُ شبَّ على \\
\hline
\end{tabular}

Nafu bagaikan balita yang masih menyusu pada ibunya, bila dibiarkan dia hendak senantiasa menyusu, bila dilepas ia tidak hendak hadapi bahaya. Bila kita bias mengatur nafsu kita dari makan serta minum, perihal ini selaku wujud kinayah dari perbuatan maksiat.

$$
\text { فاصرف هواها وحاذر أن توليه }
$$

Jagalah hatimu, jauhkanlah hatimu dari kenikmatan syahwati. Waspadailah cengkramannya. Sebab dia sekali berkuasa hendak membunuhmu ataupun sangat

\begin{tabular}{|c|c|}
\hline متنسته وأحسن رعي النفس في كوفا سائمة في رياض الأعمال لئلا تتباعد في رعيها & ورإعها وهي في الأعمالِ سائمةٌ \\
\hline
\end{tabular}
tidak dia hendak mencercamu.

Jagalah nafsumu, jangan hingga jauh dari pengawasanmu. Jangan hingga nafsumu berjalan sangat jauh menikmati padang rumput yang pada kesimpulannya nanti dia hendak membangkang terhadap perintahmu serta tidak mematuhimu lagi.

Nafsu dalam kebaikan, perihal ini disamakan dengan fauna yang digembalakan di padang rumput. Nafsu terkadang berbaur jadi satu dengan takabur.

\begin{tabular}{|c|c|}
\hline 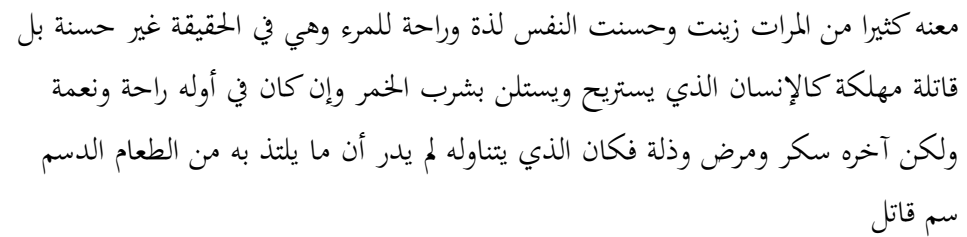 & كم حسنت لذةً للمريٍ قاتلة \\
\hline
\end{tabular}
Demikian pula fauna yang digembalakan dipadang rumput.

Kerapkali kelezatan serta ketenangan dihiasi oleh nafsu, sejatinya ia ialah sesuatu yang bersifat merusak dan membunuh. Hal ini diibaratkan dengan manusia yang malah merasa tenang dengan cara meminum tuak, sehingga ia merasakan 
kenikmatan pada mulanya, namun berikutnya ia mabuk, sakit dan merasakan kehinaan.

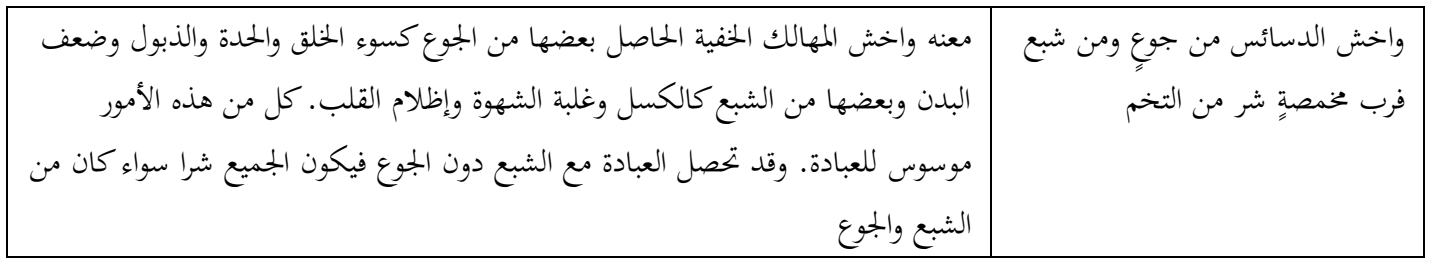

Rasa lapar, sikap kurang baik, marah serta lemahnya tubuh bisa menyebabkan malapetaka, begitupula dengan rasa kenyang, membolehkan tumbuhnya rasa malas serta hitam hati. Keduanya jadi penghalang dalam beribadah. Lapar ataupun kenyang merupakan perihal kurang baik yang jadi penghalang ibadah kepada Allah dengan khusyu'

\begin{tabular}{|c|c|}
\hline 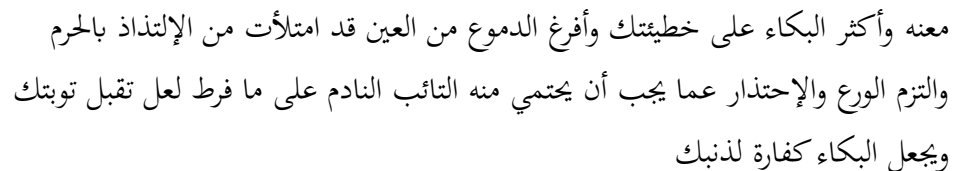 & واستفرغ الدمع من عين قد امتلأت \\
\hline
\end{tabular}

Menangislah atas kesalahanmu. Air mata yang pernah berderai karena kenikmatan haram. Pertahankanlah wara'. Semoga Allah menerima taubatmu. Mudah-mudahan air matamu menjadi salah satu penebus kesalahan berdosa yang telah kamu lakukan.

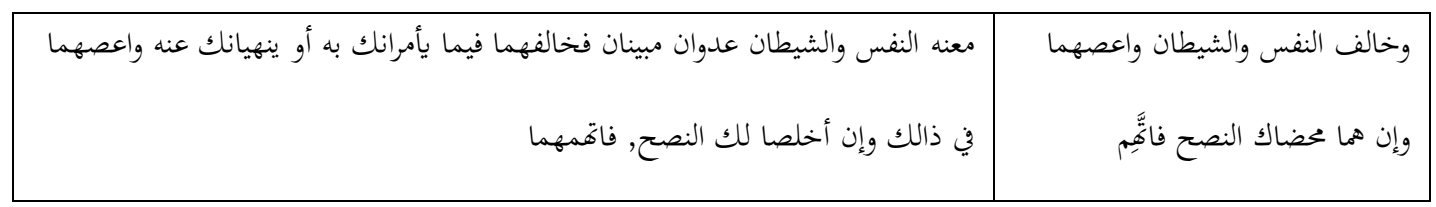

Dua musuh yang nyata yaitu nafsu dan setan. Jangan sampai terpedaya. Lawanlah keduanya. Bisa jadi mereka bermain-main dengan perintah maupun larangan yang mereka buat. Bahkan nasehatnya pun perlu dicurigai demi kebaikan kita semua.

فأنت تعرف كيد الخصم والحهما خصماً ولا حكماً


Kita tidak boleh percaya terhadap apa yang telah dinasehatkan oleh setan dan nafsu. Hal ini merupakan musuh sekaligus hakim untuk kita semua. Kita semua tahu tipu daya setan dan kezhaliman hakim yang fanatik. Maka kita harus berhati-hati.

\begin{tabular}{|c|c|}
\hline 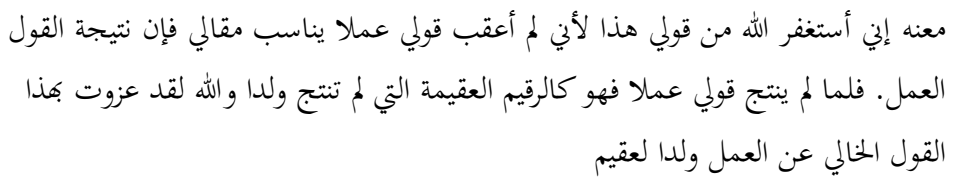 & 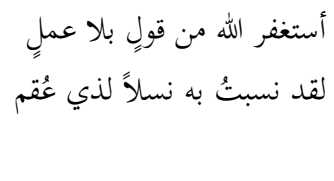 \\
\hline
\end{tabular}

Saya sudah berupaya meminta ampun kepada Allah atas apa yang sudah saya jalani, saya merasa cuma mengucapkan tanpa melaksanakan. Sementara itu tiap perkataan harusnya diiringi dengan pertanggungjawaban melaksanakan perbuatan. Perkataanku ibarat wanita mandul yang tidak mempunyai generasi.

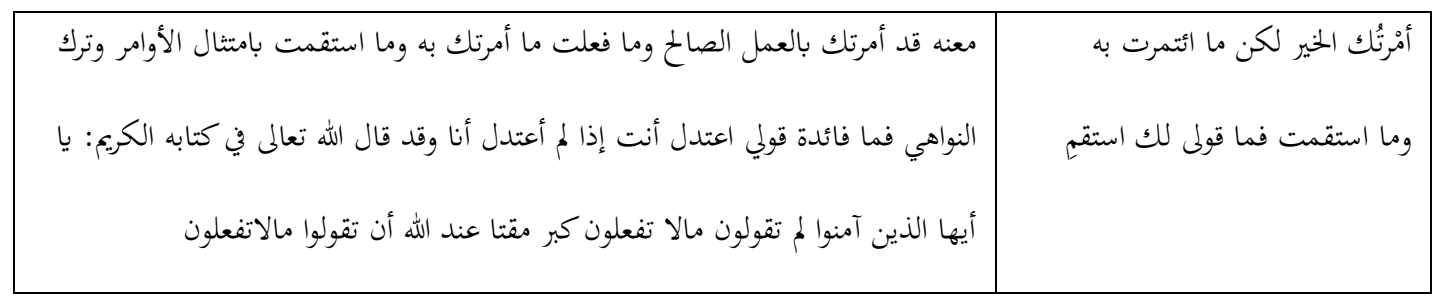

Aku telah menganjurkan kebaikan, tapi diriku pribadi tidak melaksanakannya dan tidak pula bisa menjalankannya dengan kontinyu. Maka apakah ada manfaatnya apa yang aku katakan jika diriku juga tidak bisa bijaksana dalam melaksanakan nasehatku. Allah Swt. telah mengingatkan didalam Al-Qur'an bahwa kemarahan besar dari Allah Swt. akan dating kepada otang yang mengucapkan kata-kata bijak (nasehat), namun mereka enggan sendiri melakukannya.

ولم ولا تزودت قبل الموت نافلةً

Sebelum kematian menjemputku, aku belum mempersiapkan bekal amal-amal sunnah, kecuali aku hanya mempunyai persiapan berupa shalat dan puasa yang wajib saja.

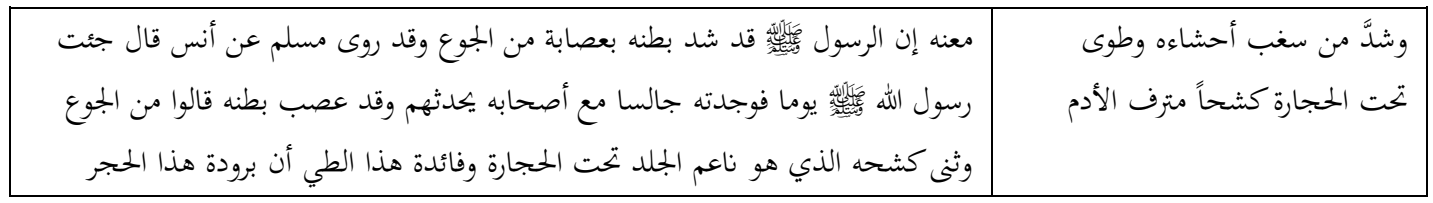




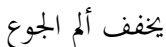

Pada suatu hari Rasulullah Saw. telah mengikat perut dan mengganjalnya dengan batu sebagai usaha untuk menahan laparnya. Sebagaimana yang telah dijelaskan di dalam hadits riwayat Muslim dari Anas ra. "Pada suatu hari saya menjumpai Rasulullah Saw. sedang bercakap-cakap dengan para sahabatnya. Dan terlihat beliau melipat kulit pinggangnya yang halus dengan batu”.

Adapun manfaat dari dari mengganjal batu pada lipatan kulit perut yang seperti dilakukan oleh Rasulullah Saw. ini adalah bahwa dinginnya batu ini dapat meringankan perihnya rasa lapar.”

وراودته الجبال الشم من ذهبٍ

Sesungguhnya deretan gunung-gunung yang menjulang tinggi yang terbuat dari emas murni itu telah membujuk rayu Rasulullah Saw. Sementara Beliau berpaling dan menolak dengan memperlihatkan ketidak-butuhannya. Karena Beliau menyadari bahwa, yang ada pada Allah Swt. akan lebih baik dan abadi.

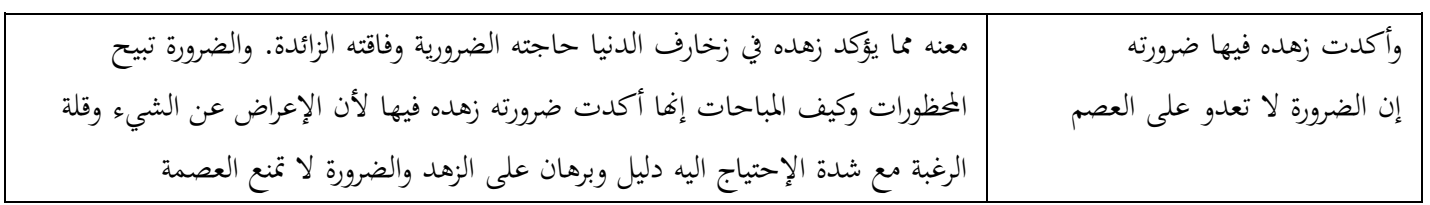

Adapun hal yang memperkuat kezuhudan beliau terhadap keindahan duniawi yaitu kebutuhan yang bersifat darurat serta adanya kesusahan yang amat, padahal kondisi darurat pada dasarnya dapat memberikan keluasan pada manusia untuk berbuat apa saja tanpa berlebihan, apalagi hal-hal yang bersifat mubah. Akan tetapi Rasulullah telah berpaling dari padanya. Hal yang demikian ini tentu makin memperkokoh kezuhudan beliau. Padahal keadaan darurat seperti yang dialami beliau tidak akan mengurangi sifat maksumnya beliau.

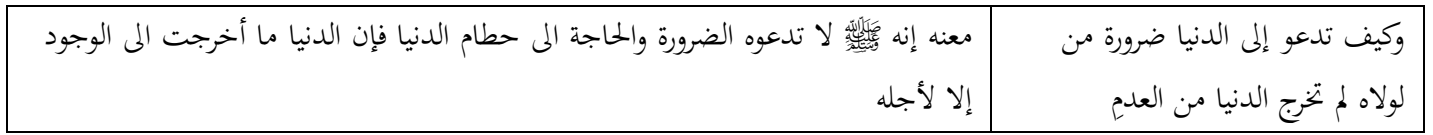


Rasulullah Saw. sebetulnya tidak bisa dituntut oleh kondisi apapun, juga kondisi darurat, hakikatnya dunia tidak ada, kecuali sebab terdapatnya Rasulullah Saw itu sendiri.

\begin{tabular}{|c|c|}
\hline 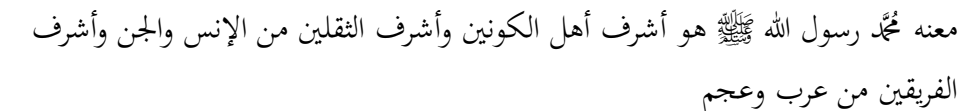 & والفرحمَّ سيد الكونين والثقلين \\
\hline
\end{tabular}

Nabi Muhammad, Rasulullah SAW adalah manusia yang paling mulia diantara semua makhluk penghuni dunia dan akhirat, paling mulia di antara manusia dan jin serta paling mulia di antara golongan Arab dan Ajam (non Arab).

\begin{tabular}{|c|c|}
\hline 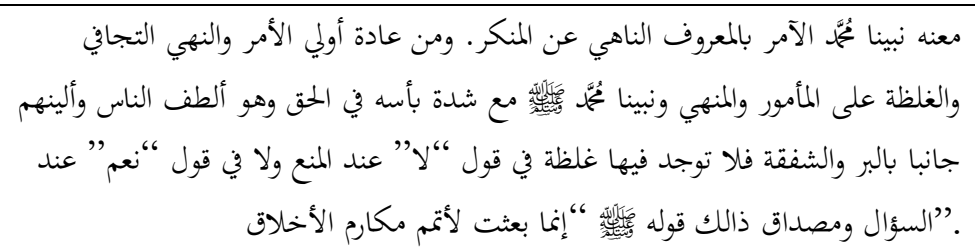 & نبينا الآمرُ الناهي فلا أحلد. \\
\hline
\end{tabular}

Nabi kita Muhammad SAW adalah orang yang menganjurkan kebaikan serta melarang keburukan. Adalah sebuah kebiasaan para penguasa dalam memerintah maupun melarang rakyatnya itu dengan cara kekerasan. Tidak sebagaimana Nabi Muhammad Saw. sekalipun beliau begitu pemberani akan tetapi beliau merupakan manusia yang paling lemah lembut dan ramah tamah. Tak pernah terdapat kekerasan dalam kata-katanya baik pada saat menolak maupun pada saat menerima. Maka tepatlah perilaku beliau dengan sabda beliau yang berbunyi: "Sesungguhnya aku diutus tidak lain kecuali untuk menyempurnkan budi pekerti.

$$
\text { لكو لكو الحبيب الذي ترجى شفاعته الأهوال مقتحم }
$$

Beliau adalah seorang kekasih Allah yang tercinta yang selalu diharapkan syafaatnya pada hari kiamat nanti dari berbagai macam ketakutan bagi siapapun yang

\begin{tabular}{|c|c|}
\hline \multirow[t]{2}{*}{ 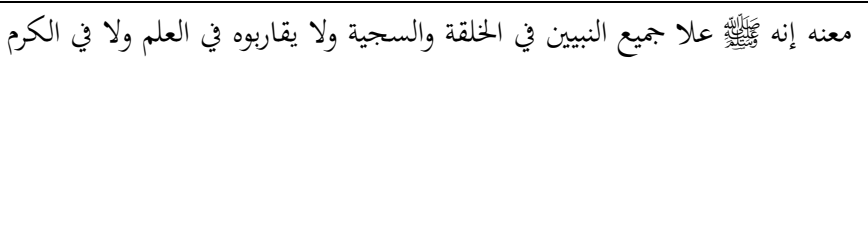 } & دعاعمسكون بحبلٍ غير منفصم الله فالمستمسكون به \\
\hline & 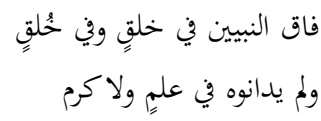 \\
\hline
\end{tabular}
melihat dan menyaksikannya karena saking dahsyatnya kejadian pada hari itu. 
Nabi Muhammad merupakan penutup para nabi dan rasul. Nabi Muhammad mempunyai keistimewaan dan kelebihan jika dibandingkan dengan nabi-nabi yang lain, baik dalam segi ketampanan (fisik secara umum) maupun budi pekertinya. Dan tidak seorang pun dari nabi-nabi itu menyamai ilmu serta kemuliaannya.

\begin{tabular}{|c|c|}
\hline 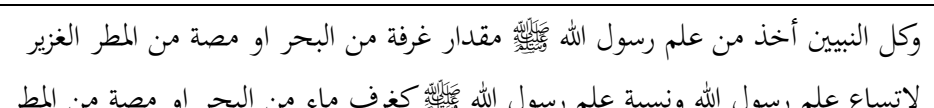 & الح رسول الله ملتمسنُ \\
\hline & نـ الديكِ \\
\hline
\end{tabular}

Ilmu Rasulullah begitu luar biasa, para nabi telah meneguk ilmu dari ilmu Rasululllah SAW. Diibaratkan mengambil seciduk air laut atau meneguk sedikit dari hujan yang lebat, demikian perbandingan betapa luasnya ilmu Rasululllah SAW yang semisal luasnya laut dan limpahan air hujan yang kemudian diteguk hanya sedikit saja.

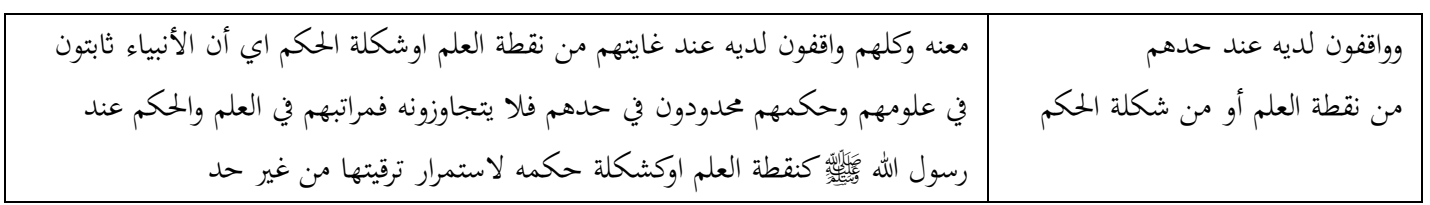

Dan semuanya berdiri pada puncaknya yang hanya baru setitik ilmu dan sebentuk hikmahnya. Hal ini mengartikan bahwa, ilmu dan hikmah para nabi bersifat statis dan terbatas pada batas keilmuan yang telah Allah tentukan. Tidak sebagaimana ilmu dan hikmah Rasulullah SAW yang senantiasa mengalami peningkatan tanpa batas.

فمهو الذي تم معناه وصورته

Maka dialah seorang nabi yang telah mencapai puncak kesempurnaan batin serta kesempurnaan sifat-sifat lahiriyahnya. Kemudian ia dipilih oleh Sang Pencipta manusia sebagai kekasihnya.

Syair-syair sholawat burdah di atas menceritakan keutamanaan sifat dan sikap Rasulullah Muhammad SAW Jika dikaitkan dengan teori belajar sosial Albert Bandura, tentang teori belajar sosial, Interaksi antara klien dengan lingkungan dapat memodifikasi suatu perilaku. Teknik modeling adalah salah satu teknik konseling yang disusun sesuai teori Albert Bandura. Teknik modeling (peniruan) diterapkan apabila konseling memiliki tujuan untuk menciptakan suatu perilaku baru bagi klien. 
Teknik modeling (peniruan) ini menjadi salah satu teknik paling efektif yang dapat memberikan dampak positif terhadap peserta didik. Seorang pendidik memberikan contoh untuk bertingkah laku yang baik, keteladanan yang baik berdasarkan ajaran Rasulullah SAW terutama sesuai dengan sholawat burdah, secara otomatis jika hal itu terjadi berulang-ulang, maka akan ditirukan oleh peserta didik.

Nilai-nilai keteladanan di dalam sholawat burdah memberikan dampak positif pada kedua belah pihak, baik pendidik maupun peserta didik. Nilai-nilai yang termaktub dapat dipelajari dan diamalkan di dalam kehidupan sehari-hari. Dengan pengamalan nilai-nilai dalam sholawat burdah yang sesuai dengan teori sosial Albert Bandura akan menciptakan siklus pembelajaran yang baik, hingga akhirnya membentuk pelajar sebagai insan kamil.

Malalui syair-syair sholawat burdah ini diharapkan, baik pendidik maupun peserta didik dapat mengambil keteladanan dalam proses pembelajaran. Kecintaan Imam Al-Bushiri kepada Rasulullah SAW. yang sangat tinggi hingga apa yang beliau ungkapkan melalui syair-syair sholawat burdah merupakan salah satu yang dapat kita amalkan dalam kehidupan sehari-hari. Gambaran keistimewaan Rasulullah SAW. yang ada di syair-syair sholawat burdah bisa dijadikan sebagai role mode, pendidikan keteladanan dalam proses pembelajaran.

\section{Kesimpulan}

Di dalam pendidikan Islam, keteladanan merupakan salah satu metode influentif yang memberikan dampak keberhasilan besar di dalam mempersiapkan dan mebentuk karakter anak secara moral, spiritual, dan sosial. Qashidah burdah melalui sya'ir-sya'ir nya yang begitu indah, yang menceritakan kisah Rasulullah yang terpilih, ditulis oleh seorang penyair yang alim. Menurut teori social learning, interaksi antara klien dengan lingkungan dapat menjadi faktor modifikasi suatu perilaku. Teknik modeling adalah salah satu cara dalam konseling yang disiapkan sesuai dengan teori Albert Bandura. Riset ini bertujuan untuk menganalisis nilai-nilai pendidikan keteladanan didalam syair-syair qasidah burdah dan relevansinya terhadap teori belajar sosial Albert Bandura. Penerapan dari riset ini diharapkan dapat dijadikan 
sebagai gagasan pendekatan dalam proses pembelajaran untuk mengembangkan kapasitas belajar dengan metode keteladanan.

Rekomendasi untuk riset selanjutnya adalah, penerapan metode pendidikan keteladanan yang ada di dalam sholawat burdah yang terkandung dalam mata pelajaran Pendidikan Agama Islam untuk semua instansi pendidikan, tidak hanya di dalam pesantren melainkan di dalam semua instansi pendidikan. Penerapan metode pendidikan ini dapat dilakukan dengan mengkaji sholawat burdah pada lembaga pendidikan, menciptakan pembiasaan pembacaan dan mengamalkan sholawat burdah pada diri siswa.

\section{Referensi}

Abdul, Asnawi, Muhid, Rangga Sa'adillah. "Pendidikan Moral Melalui Pembelajaran Kitab Alfiyah Ibn Malik di Pondok Pesantren Langitan Tuban." Jurnal Pendidikan Agama Islam (Journal of Islamic Education Studies) 6, no. 1 (2018), 106126.

Achmadi, Ishom. 2014. Kaifa Nurobbi Abnaa Ana. Edited by Hubby and Al-Fatib ElJawy. Yogyakarta: SJ Press.

Al-Bajuri, Ibrahim. Kitab Syarah Al-Bajuri 'ala Al-Burdah Al-Bushiri.

Muhammad Jamaluddin, Al Qasimy. 1914. Tafsir Al Qasimy Al Musamma Mahasinu Al Takwiil. Bairut: Darul Fikr.

Bandura, Albert. "Social Cognitive Theory in Cultural Context." Applied Psychology 51, no. 2 (2002), 280.

Hasan, M. Iqbal. 2002. Pokok-Pokok Materi Metodologi Riset dan Aplikasinya. Jakarta: Ghalia Indonesia.

Kartono, Kartini. 2002. Psikologi Sosial Untuk Manajemen Perusahaan dan Industri. Jakarta: PT Raja Grafindo Persada.

Manshur. 2007. Kasidah Burdah Al-Bushiry dan Popularitasnya dalam Berbagai Tradisi; Suntingan Teks, Terjemahan dan Telaah Resepsi. Yogyakarta: Universitas Gadjah Mada.

Muhid, Abdul. 2015. Psikologi Pendidikan. Surabaya: Digilib Uinsa.

Mustofa, Ali. "Metode Keteladanan Perspektif Pendidikan Islam," CENDEKLA: Jurnal Studi Keislaman 5, no. 1 (2019). 23-42.

Muthohar, Sofa. "Antisipasi Degradasi Moral di Era Global," Nadwa: Jurnal Pendidikan Islam, 7, no. 2 (2013), 321-334.

Nata, Abudin. 1996. Akblak Tasawnf. Jakarta: RajaGrafindo Persada.

186 | Tarbiyatuna: Jurnal Pendidikan Islam; Volume 14, Nomor 2, Agustus 2021 p-ISSN: 2085-6539; e-ISSN: 2242-4579; 164-187 
Nihayah, Ulin. "Qasidah Burdah Imam Al-Bushiri; Model Alternatif Dakwah Pesantren.” An-Nida: Jurnal Komunikasi Islam 7, no. 1 (2015), 30-38.

Qoyim, Dinul. Al Burdah.

Safrony, M. Ladzi. 2013. Al-Ghazali Berbicara Tentang Pendidikan Islam. Yogyakarta: Aditya Media Publishing.

Shaikh. Zarnuji (al). 2010. Ta'lim Al-Muta'allim. Tt. Surabaya: Al Hidayah.

Solikin, Asep. "Nilai-Nilai Spiritual Sufistik Qasidah Burdah dalam Meningkatkan Religiusitas.” Anterior, Anterior 15, no. 1 (2015), 21-29.

Sulthani, Dinil Abrar. "Internalisasi Pendidikan Agama dalam Membentuk Masyarakat Madani." TARBIYATUNA 14, no. 1 (2021), 87-100.

Taklimudin, Febri Saputra. "Metode Keteladanan Pendidikan Islam Dalam Persfektif Quran.” BELAJEA: Jurnal Pendidikan Islam 3, no. 1 (2018), 1-22.

Tarsono, "Implikasi Teori Belajar Sosial (Social Learning Theory) dari Albert Bandura dalam Bimbingan dan Konseling," Psympathic, vol 3, no. 1 (2010). 29-36.

Tholkhah, Imam \& Barizi, Ahmad. 2004. Membuka Jendela Pendidikan. Jakarta: Rajawali Pers.

Ulwan, Abdullah Nashih. 2007. Pendidikan Anak dalam Islam, ter, Jamaludin Miri. Jakarta: Pustaka Amani.

Walgito, Bimo. 2004. Pengantar Psikologi Umum. Yogyakarta: Andi Offset.

Wiyani, Novan Ardy dan Barnawi. 2016. Ilmu Pendidikan Islam. Yogyakarta: Ar-Ruzz Media. 